\title{
Threatened fishes of the world: Heteropneustus fossilis (Bloch, 1794) (Siluriformes: Heteropneustidae)
}

\author{
M. A. Haniffa • M. Dhanaraj • \\ C. Muthu Ramakrishnan • \\ T. A. Sethuramalingam - S. V. Arun Singh • \\ Y. Ananth Kumar • R. Arthi Manju
}

Published online: 10 January 2008

(C) Springer Science + Business Media B.V. 2007

The title of the article "Threatened fishes of the world: Heteropneustes fossilis (Bloch, 1794) (Cypriniformes: Saccobranchidae)" should be read as "Threatened fishes of the world: Heteropneustus fossilis (Bloch, 1794) (Siluriformes: Heteropneustidae)'.

The online version of the original article can be found at http:// dx.doi.org/10.1007/s10641-007-9314-6.

M. A. Haniffa $(\bowtie) \cdot$ M. Dhanaraj •

C. Muthu Ramakrishnan - T. A. Sethuramalingam •

S. V. Arun Singh · Y. Ananth Kumar · R. Arthi Manju

Centre for Aquaculture Research and Extension (CARE),

St. Xavier's College (Autonomous),

Palayamkottai 627-002 Tamil Nadu, India

e-mail: haniffacare@gmail.com 